\title{
Echinacoside induces apoptotic cancer cell death by inhibiting the nucleotide pool sanitizing enzyme MTHI
}

This article was published in the following Dove Press journal:

OncoTargets and Therapy

8 December 2015

Number of times this article has been viewed

\section{Liwei Dong' \\ Hongge Wang' \\ Jiajing Niu' \\ Mingwei Zou ${ }^{2}$ \\ Nuoting $\mathrm{Wu}^{\prime}$ \\ Debin $\mathrm{Yu}^{\prime}$ \\ Ye Wang' \\ Zhihua Zou'}

'Key Laboratory for Molecular Enzymology and Engineering of the Ministry of Education, National Engineering Laboratory for AIDS Vaccine, School of Life Sciences, Jilin University, Changchun, Jilin Province, People's Republic of China; ${ }^{2}$ Department of Psychology, College of Liberal Arts and Social Sciences, University of Houston, Houston, TX, USA
Correspondence: Zhihua Zou School of Life Sciences, Jilin University, 2699 Qianjin Street, Changchun, Jilin Province 130012, People's Republic of China

Tel +86 43I 85I5 5349

Fax +86 43I 85I 5349

Email zouzh@jlu.edu.cn

\begin{abstract}
Inhibition of the nucleotide pool sanitizing enzyme MTH1 causes extensive oxidative DNA damages and apoptosis in cancer cells and hence may be used as an anticancer strategy. As natural products have been a rich source of medicinal chemicals, in the present study, we used the MTH1-catalyzed enzymatic reaction as a high-throughput in vitro screening assay to search for natural compounds capable of inhibiting MTH1. Echinacoside, a compound derived from the medicinal plants Cistanche and Echinacea, effectively inhibited the catalytic activity of MTH1 in an in vitro assay. Treatment of various human cancer cell lines with Echinacoside resulted in a significant increase in the cellular level of oxidized guanine (8-oxoguanine), while cellular reactive oxygen species level remained unchanged, indicating that Echinacoside also inhibited the activity of cellular MTH1. Consequently, Echinacoside treatment induced an immediate and dramatic increase in DNA damage markers and upregulation of the G1/S-CDK inhibitor p21, which were followed by marked apoptotic cell death and cell cycle arrest in cancer but not in noncancer cells. Taken together, these studies identified a natural compound as an MTH1 inhibitor and suggest that natural products can be an important source of anticancer agents.
\end{abstract}

Keywords: Echinacoside, MTH1, 8-oxoG, DNA damage, apoptosis, cell cycle arrest

\section{Introduction}

The cellular and mitochondrial nucleoside triphosphate (NTP) and deoxynucleoside triphosphate (dNTP) pool is a significant target of various reactive oxygen species (ROS). ${ }^{1-3}$ Because the specificity of DNA polymerases is less than perfect, ${ }^{4,5}$ oxidized dNTPs can be incorporated into newly synthesized DNA to cause genetic aberrations if not fixed. ${ }^{6}$ For example, the major oxidized base in the nucleotide pool, 8-oxoguanine (8-oxoG), can base pair with cytosine and adenine. When inserted into opposite adenine during DNA replication, it can potentially cause $\mathrm{T}: \mathrm{A}=\mathrm{G}: \mathrm{C}$ transversion, ${ }^{7}$ which is one of the most common mutations found in human cancers. ${ }^{8,9}$ Although most of the oxidized free dNTPs are removed by nucleotide pool sanitizing enzymes, studies in the past have revealed that the nucleotide pool is still an important source of oxidized bases in DNA molecules and a significant contributor of oxidative DNA damages. ${ }^{3,10}$

Mammalian cells are armed with sophisticated defense mechanisms to minimize ROS-induced genomic lesions. Nucleotide pool sanitizing enzymes hydrolyze oxidized dNTPs and NTPs, thus preventing their incorporation into DNA and RNA molecules. ${ }^{11,12}$ MTH1, a member of the Nudix hydrolase superfamily (hence also called NUDT1 $),{ }^{13}$ is a triphosphatase responsible for removing oxidized purine NTPs and dNTPs (8-oxodGTP, 2-OH-dATP, 8-OH-GTP, and 2-OH-ATP) from the nucleotide pools. ${ }^{14}$ Since 8 -oxoguanine $(8-0 x o G)$ is the major oxidized base inside cells, MTH1 is 
the most important enzyme for the sanitization of nucleotide pools. ${ }^{15}$ Nevertheless, even under the surveillance by the nucleotide pool sanitizing enzymes, a significant portion of oxidized dNTPs is incorporated into DNA, and bases in DNA molecules can also be oxidized directly by ROS. ${ }^{6}$ Cells then rely on more elaborated strategies involving various DNA glycosylases, such as OGG1 and MUTYH, and DNA repair processes, including base excision repair (BER) and mismatch repair (MMR), to fix problematic bases in DNA molecules. ${ }^{10,16,17}$ BER and MMR normally repair numerous oxidized bases in DNA per day and thus play important roles in protecting the integrity and stability of the genome.

In cells that are under elevated oxidative stress, increased incorporation of oxidized nucleotides into DNA may overwhelm the cellular repair capacity and trigger DNA damage response (DDR). ${ }^{18}$ Persistent DDR signaling will lead to cell cycle arrest, premature cellular senescence, or apoptosis, thus setting a barrier for tumorigenesis. ${ }^{19}$ Yet, although cancer cells display highly increased oxidative tension and generate a potentially lethal burden of oxidized nucleotides, ${ }^{20}$ they can survive the DDR-associated senescence or apoptosis. ${ }^{21}$ A large number of studies have shown that MTH1, by effectively removing the dangerously abundant 8-oxodGTP and 2-OH-dATP in tumor cells, plays a key role in the development of cancer. ${ }^{22} \mathrm{MTH} 1$ was found to be overexpressed in different types of cancer, ${ }^{23-25}$ and 8-oxoG level and the extent of oxidative DNA lesions were lower in tumors than in the surrounding normal tissues. ${ }^{26-28}$ Functionally, the overexpression of MTH1 significantly reduced the number of DNA mutations seen in MMR-deficient mouse embryonic fibroblasts ${ }^{10}$ and allowed cells to overcome oncogenic Ras-induced premature cellular senescence and apoptosis; ${ }^{29}$ whereas the suppression of MTH1 prevented the development of cancer in $O G G 1$-deficient mice ${ }^{30}$ and promoted ROS-induced DDR and cellular senescence in Ras-transformed cells. ${ }^{3,29,31}$ Thus, although MTH1 plays a protective role by preventing ROS-induced mutations in healthy cells, these studies found that MTH1 is particularly required for the emergence and survival of cancer cells. Recent studies have provided more evidence to support the role of MTH1 in cancer development. ${ }^{31-34}$ Suppression of MTH1 by RNAi or small molecule inhibitors in various cancer cell lines resulted in markedly increased incorporation of 8-oxodG into genomic DNA, leading to extensive DNA damages, apoptotic cell death, and reduced cancer cell survival. ${ }^{32,33}$ In mouse xenograft studies, inhibition of MTH1 efficiently suppressed the growth of cancer explants. Importantly, suppressing MTH1 did not impact the growth and survival of normal cells, probably because normal cells have lower ROS and hence are less dependent on MTH1 for survival. $^{32,33}$ These findings suggest that inhibition of MTH1 is a promising novel strategy to fight cancer.

Natural products have been a rich source of medicinal compounds. ${ }^{35}$ Many modern therapeutics, including anticancer drugs, have been derived from herbal or botanical preparations. ${ }^{36-39}$ Still, a large number of traditional herbs proposed to possess various therapeutic properties remain to be characterized, largely due to difficulties in controlling their compositions to unambiguously define their efficacy and mechanisms of action. ${ }^{40}$ New approaches that allow for detection of active compounds and analysis of molecular mechanisms are needed. In this regard, target-guided highthroughput in vitro screening can be instrumental in finding mechanistically defined medicinal compounds from natural resources. In the present study, we used the MTH1-catalyzed enzymatic reaction as a high-throughput in vitro assay to search for natural compounds that can inhibit MTH1. Surprisingly, the screening revealed that Echinacoside, a natural product that is best known for its potent antioxidative activity, is capable of inhibiting MTH1.

\section{Materials and methods Materials}

Natural herbal compounds were purchased from Yuanye Biological Technology Co., Shanghai, People's Republic of China. The name, catalog number, Chemical Abstracts Service (CAS) registry number, and purity of each compound are listed in Table S1. Stock solutions of the compounds were prepared in $100 \%$ dimethyl sulfoxide (DMSO) (Sigma-Aldrich, St Louis, MO, USA), and working solutions were prepared in assay buffer or complete cell culture medium. The same solution without the test compound but containing the same amount of DMSO was used as vehicle control. (S)-crizotinib was purchased from Selleck Chemicals, Houston, TX, USA.

\section{In vitro screening}

The in vitro enzymatic assay used to screen natural herbal compounds followed the procedures described by Gad et al. ${ }^{32}$ Briefly, serial dilutions of individual compounds were prepared in the assay buffer consisting of $100 \mathrm{mM}$ Tris-acetate ( $\mathrm{pH} 8.0$ ), $40 \mathrm{mM} \mathrm{NaCl}, 10 \mathrm{mM} \mathrm{Mg}$ acetate, $0.005 \%$ Tween 20, and $1 \mathrm{mM}$ DTT. Next, $0.5 \mathrm{nM}$ recombinant human MTH1 (Abcam, Cambridge, UK), $100 \mu \mathrm{M}$ dGTP (Thermo Fisher Scientific, Waltham, MA, USA), and $0.2 \mathrm{U} / \mathrm{mL}$ inorganic pyrophosphatase (Thermo Fisher Scientific) were added, and the plates were incubated on a plate shaker for 1 hour at 
room temperature. The final reaction volume was $100 \mu \mathrm{L}$ in a 96-well plate. At the end of the reaction, malachite green (J\&K Scientific, Beijing, People's Republic of China) was added, ${ }^{41}$ and the plates were incubated at room temperature for another 15 minutes. Absorbance at $630 \mathrm{~nm}$ was measured by a BioRad 680 microplate reader (Bio-Rad Laboratories Inc., Hercules, CA, USA). Inhibitory concentration ( $\left.\mathrm{IC}_{50}\right)$ values were determined by nonlinear regression analysis using the GraphPad Prism software.

\section{Cell culture}

Human MG-63 osteosarcoma, SK-HEP-1 hepatocarcinoma, MCF7 breast cancer, SW480 colorectal cancer, HEK293 embryonic kidney, and mouse NIH/3T3 fibroblast cell lines were from American Type Culture Collection, and the human normal liver cell line L-O2 was purchased from KenGen Biotech, Nanjing, People's Republic of China. These cells were maintained at $37^{\circ} \mathrm{C}$ in a humidified atmosphere with $5 \% \mathrm{CO}_{2}$, following instructions given by the providers. No ethics statement was required from the institutional review board for the use of these cell lines.

\section{Measurement of intracellular 8-oxoG}

Intracellular 8-oxoG levels were measured by staining with Cy3-conjugated avidin. ${ }^{42} \mathrm{~A}$ total of $1 \times 10^{4}$ cells were seeded on a round coverslip in 12-well plates. Next day, the cells were treated with $0 \mu \mathrm{M}, 15 \mu \mathrm{M}, 30 \mu \mathrm{M}, 60 \mu \mathrm{M}$, or $80 \mu \mathrm{M}$ Echinacoside for 5 hours, 12 hours, or 24 hours and were then fixed with ice-cold methanol for 20 minutes, followed by incubation in Tris-buffered saline (TBS) with $0.1 \%$ Triton X-100 (Sigma-Aldrich) for 15 minutes. The samples were blocked in TBS with $0.1 \%$ Triton X-100 and 15\% fetal bovine serum for 1 hour at room temperature and then stained with Cy3-conjugated avidin $(0.5 \mu \mathrm{g} / \mathrm{mL})$ (Rockland Immunochemicals, Limerick, PA, USA) in blocking solution for 1 hour at $37^{\circ} \mathrm{C}$. After washing in phosphate-buffered saline (PBS) for 3 times for 5 minutes, the coverslips were sealed on glass slides in VECTASHIELD Mounting Medium with 4',6-diamidino-2-phenylindole (Vector Laboratories, Burlingame, CA, USA). Images were taken and analyzed by a Zeiss LCM 510 confocal microscope.

\section{Measurement of intracellular ROS}

Intracellular ROS levels were measured by flow cytometry using a cell-based ROS assay kit (Beyotime Biotechnology, Haimen, People's Republic of China). Cells grown in sixwell plates were treated with $0 \mu \mathrm{M}, 15 \mu \mathrm{M}, 30 \mu \mathrm{M}, 60 \mu \mathrm{M}$, or $80 \mu \mathrm{M}$ Echinacoside for 5 hours, 12 hours, or 24 hours, washed twice with PBS, and incubated with $10 \mu \mathrm{M}$ dichlorofluorescin diacetate for 30 minutes at $37^{\circ} \mathrm{C}$. The cells were then trypsinized and analyzed by the FACSCaliber flow cytometer (BD Biosciences, San Jose, CA, USA). Intracellular ROS levels were expressed as the average dichlorodihydrofluorescein fluorescence intensity of the cells. Numbers shown were averages of three independent experiments.

\section{Immunofluorescent staining}

Cells grown on coverslips were treated with $0 \mu \mathrm{M}, 15 \mu \mathrm{M}$, $30 \mu \mathrm{M}, 60 \mu \mathrm{M}$, or $80 \mu \mathrm{M}$ Echinacoside for 5 hours, 12 hours, or 24 hours and then washed once with PBS, fixed with $4 \%$ paraformaldehyde in PBS for 20 minutes, and blocked in TBS with $0.1 \%$ Triton $\mathrm{X}-100$ and $15 \%$ fetal bovine serum for 1 hour at room temperature. Fixed cells were stained for 2 hours at room temperature with a primary antibody against 8-oxoG (mouse monoclonal anti-8-oxoG, Abcam), 53BP1 (rabbit anti-53BP1; Bethyl Laboratories, Montgomery, TX, USA), or active caspase-3 (rabbit anti-caspase-3, Bioss, Beijing, People's Republic of China), followed by staining with an Alexa 488-conjugated donkey antimouse (Abcam) or Cy3-conjugated goat anti-rabbit (Jackson ImmunoResearch Laboratories, West Grove, PA, USA) secondary antibody for 1 hour at room temperature. After washing in PBS for 3 times for 5 minutes, the coverslips were sealed on glass slides in VECTASHIELD Mounting Medium with DAPI (Vector Laboratories). Images were taken by a Zeiss LCM 510 confocal microscope.

\section{Colony formation assay}

The day before treatment, cells were seeded in a six-well plate at a concentration of $1 \times 10^{4}$ cells per well. They were then treated with $0 \mu \mathrm{M}, 60 \mu \mathrm{M}$, or $80 \mu \mathrm{M}$ Echinacoside for 7 days. After washing with PBS, cells were fixed with icecold methanol and stained with crystal violet solution (SigmaAldrich) (0.5\% in $25 \%$ methanol). Images were photographed after drying the plates overnight. The crystal violet crystals were dissolved by adding 70\% ethanol, and absorbance at $595 \mathrm{~nm}$ was measured by a BioRad 680 microplate reader. Data were analyzed using the GraphPad Prism software.

\section{MTT assay}

One day before treatment, cells were seeded in 96-well plates at a concentration of $1 \times 10^{4}$ cells per well, followed by treatment with serial dilutions of Echinacoside for 24 hours or 48 hours, or with $60 \mu \mathrm{M}$ Echinacoside for 5 hours, 12 hours, or 24 hours. The medium was removed, and the cells were washed with PBS, and then, $20 \mu \mathrm{L}$ of 3-(4,5-dimethylthiazol-2-yl)-2, 
5-diphenyl tetrazolium bromide (MTT) solution $(5 \mathrm{mg} / \mathrm{mL}$ in PBS, pH 7.2) (Thermo Fisher Scientific) was added to each well. The plates were incubated at $37^{\circ} \mathrm{C}$ for another 4 hours. At the end, the MTT solution was removed and $150 \mu \mathrm{L}$ of DMSO was added to each well. The plates were incubated on a plate shaker for 10 minutes, and absorbance at $570 \mathrm{~nm}$ was measured by a BioRad 680 microplate reader. Each experiment was conducted twice in triplicate. Data were analyzed using the GraphPad Prism software. $\mathrm{IC}_{50}$ values were determined using nonlinear regression analysis.

\section{Cell cycle analysis}

Cells in six-well plates were treated with $0 \mu \mathrm{M}, 60 \mu \mathrm{M}$, or $80 \mu \mathrm{M}$ Echinacoside for 24 hours, harvested with trypsin (Life Technologies, Carlsbad, CA, USA), washed twice with PBS, and then fixed with ice-cold ethanol (70\%) for 2 hours at $-20^{\circ} \mathrm{C}$. Fixed cells were washed twice in cold PBS and resuspended in $300 \mu \mathrm{L}$ of freshly prepared PBS with $0.1 \%$ Triton X-100, $0.2 \mathrm{mg} / \mathrm{mL}$ DNase-free RNase A (SigmaAldrich), $10 \mu \mathrm{g} / \mathrm{mL}$ propidium iodide (PI) (Hoffman-La Roche Ltd., Basel, Switzerland). After incubation at $37^{\circ} \mathrm{C}$ in the dark for 20 minutes, the cells were filtered through a Filcon nylon mesh (BD Biosciences), loaded onto the FACSCalibur flow cytometer, and analyzed using the ModFit software (BD Biosciences).

\section{DNA fragmentation analysis}

Cells grown in six-well plates were treated with $0 \mu \mathrm{M}$, $60 \mu \mathrm{M}$, or $80 \mu \mathrm{M}$ Echinacoside for 24 hours and fixed in ice-cold 4\% paraformaldehyde (Sigma-Aldrich) for 20 minutes. After washing with PBS, cells were sealed in VECTASHIELD Mounting Medium with DAPI (Vector Laboratories). Nuclear morphology was photographed with an Olympus fluorescent microscope. To detect DNA fragmentation on agarose gels, DNA was extracted using the QIAamp DNA micro kit (Qiagen NV, Venlo, the Netherlands), and electrophoresis was performed on $2 \%$ agarose gels containing $0.1 \mu \mathrm{g} / \mathrm{mL}$ ethidium bromide.

\section{Analysis of apoptosis by flow cytometry}

Apoptotic cells were examined using an Annexin V-FITC Apoptosis detection kit (Bestbio, Shanghai, People's Republic of China), following the manufacturer's instructions. Cells grown in 96-well plates were treated with $0 \mu \mathrm{M}, 15 \mu \mathrm{M}$, $30 \mu \mathrm{M}, 60 \mu \mathrm{M}, 80 \mu \mathrm{M}$, or $160 \mu \mathrm{M}$ Echinacoside for 2 hours, 5 hours, 12 hours, or 24 hours, washed twice with PBS, and then resuspended in a binding buffer. Next, $5 \mu \mathrm{L}$ of Annexin V-FITC and $5 \mu \mathrm{L}$ of PI (Roche) were added sequentially, and the cells were incubated for 15 minutes in the dark at room temperature. The cells were loaded onto the FACSCalibur flow cytometer (BD Biosciences), and data were analyzed using the Cell Quest software (BD Biosciences).

\section{Western blot analysis}

Cells grown in six-well plates were treated with $0 \mu \mathrm{M}$, $60 \mu \mathrm{M}$, or $80 \mu \mathrm{M}$ Echinacoside for 5 hours, 12 hours, or 24 hours, washed twice with PBS, and scraped off the plate using $100 \mu \mathrm{L}$ of radioimmunoprecipitation buffer $(150 \mathrm{mM}$ $\mathrm{NaCl}, 1.0 \%$ IGEPAL CA-630, 0.5\% sodium deoxycholate, $0.1 \%$ sodium dodecyl sulfate, and $50 \mathrm{mM}$ Tris, $\mathrm{pH} \mathrm{8.0)}$ (Sigma-Aldrich) containing $1 \mathrm{mM}$ phenylmethane sulfonylfluoride. Samples were centrifuged at $12,000 \times g$ for 20 minutes at $4{ }^{\circ} \mathrm{C}$. Protein concentrations in the supernatants were determined by the Bradford reagent (Dingguo, Changchun, People's Republic of China). Samples were denatured at $95^{\circ} \mathrm{C}$ for 10 minutes and separated on $12 \%$ sodium dodecyl sulfate-polyacrylamide gel electrophoresis gel. After electrophoresis, proteins were transferred to polyvinylidene fluoride membranes (Millipore), followed by blocking in Tris-buffered saline with Tween $20(10 \mathrm{mM}$ Tris, $\mathrm{pH} 7.5 ; 100 \mathrm{mM} \mathrm{NaCl} ; 0.1 \%$ Tween 20) containing $5 \%(\mathrm{w} / \mathrm{v})$ nonfat milk for 1 hour at room temperature. Blots were probed with primary antibodies against p21 (Abcam), poly (ADP-ribose) polymerase (Bioss), or activated caspase-3 (Bioss), followed by horse radish peroxidaseconjugated secondary antibodies (Jackson ImmunoResearch Laboratories). Signals were developed using the enhanced chemiluminescence Western blotting detection kit (Transgen Biotech, Changchun, People's Republic of China). The experiments were repeated three times.

\section{Measurement of mitochondrial membrane potential}

Mitochondrial membrane potential was measured using the JC-1 dye (Biotechnology), following the manufacturer's instructions. Cells grown in six-well plates were treated with $0 \mu \mathrm{M}, 60 \mu \mathrm{M}$, or $80 \mu \mathrm{M}$ Echinacoside for 5 hours, 12 hours, or 24 hours, washed twice in PBS, and then incubated with JC-1 for 20 minutes. Images were taken using an Olympus fluorescent microscope.

\section{Statistical analysis}

Statistical analysis was performed using the GraphPad Prism Software. Significance was calculated using one-way analysis of variance, and $P<0.05$ was considered statistically significant. Results were expressed as mean \pm standard deviation. 


\section{Results}

\section{Identification of Echinacoside as an MTHI inhibitor}

To search for natural compounds capable of inhibiting MTH1, we used the MTH1-catalyzed enzymatic reaction as a highthroughput in vitro screening assay. Besides oxidized purine nucleotides, MTH1 can also hydrolyze normal deoxyguanosine triphosphate to generate deoxyguanosine monophosphate and pyrophosphate. In the presence of excess inorganic pyrophosphatase, all pyrophosphates are converted into inorganic phosphates, which can be quantified using a malachite green-based absorbance assay, ${ }^{41}$ thus allowing for indirect measurement of MTH1 activity. ${ }^{32}$ To test the assay system, we first measured the effect of $(S)$-crizotinib, a compound with proven potency as an MTH1 inhibitor. ${ }^{33}$ The result showed that $(S)$-crizotinib indeed potently inhibited MTH1 (Figure 1A) with an $\mathrm{IC}_{50}$ of $500 \mathrm{nM}$, which was sevenfold higher than that reported by Huber et al $(72 \mathrm{nM}) .{ }^{33}$ This was likely due to the differences in the detection methods or sources of chemicals and enzymes. We adopted a less sensitive chromogenic approach, while Huber et al used a highly sensitive bioluminescent method. ${ }^{33}$ Keeping this in mind, we screened 12 commercially available natural compounds (Table S1), each of which is a major ingredient of traditional herbs with potential antitumor activity. Echinacoside, a compound purified from the parasitic medicinal plant Cistanche salsa (Figure 1C), significantly inhibited the reaction (Figure $1 \mathrm{~B}$ ), with an $\mathrm{IC}_{50}$ of $7.01 \pm 2.13 \mu \mathrm{M}$ (Figure 1D). Adding 50 times more pyrophosphatase had no impact on the result, while adding five times more MTH1 protein significantly decreased the degree of inhibition, suggesting that Echinacoside specifically inhibited the activity of MTH1 in the in vitro enzymatic assay.
A

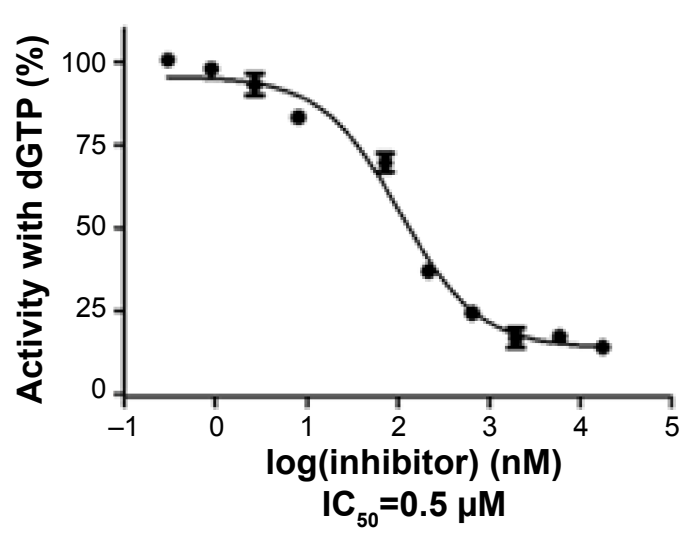

C

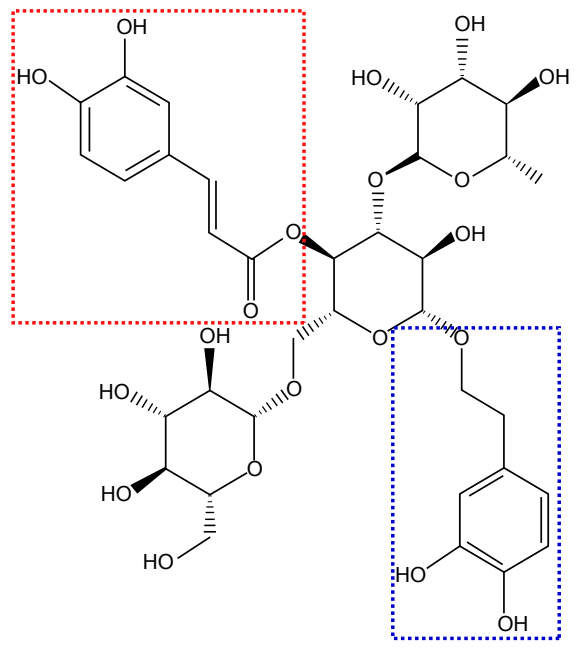

B

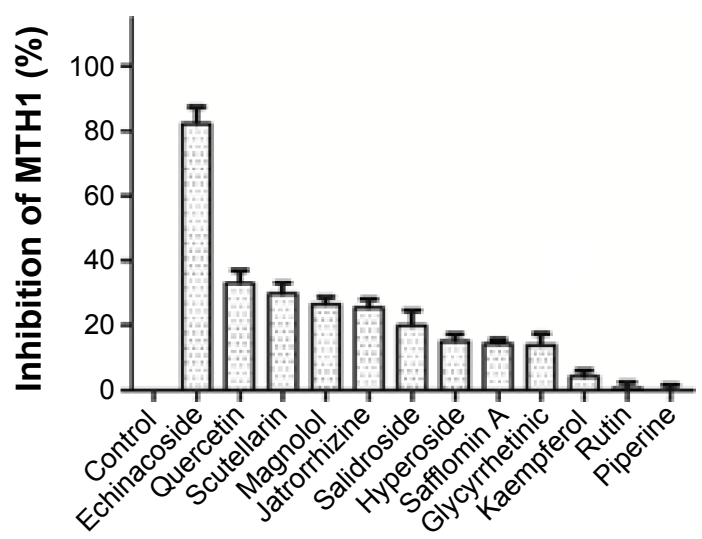

D

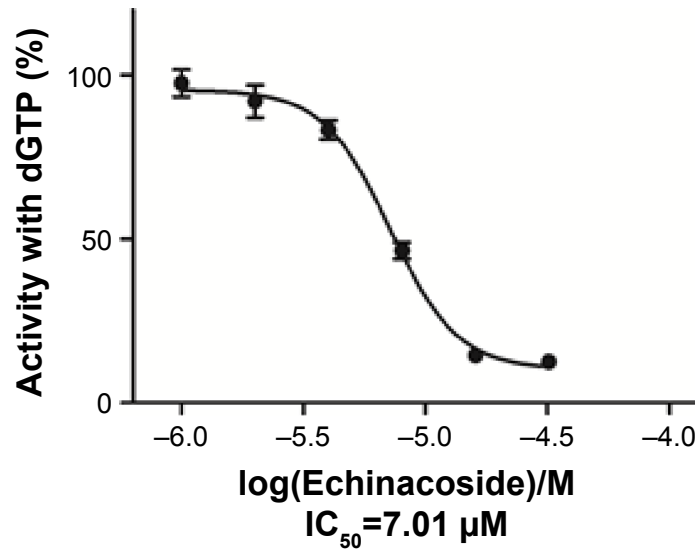

Figure I In vitro screening of natural compounds.

Notes: (A) A dose-response curve of MTHI inhibition by a positive control: (S)-crizotinib inhibited MTHI with an IC $\mathrm{C}_{50}$ of $0.5 \mu \mathrm{M}$; (B) the inhibition of MTHI by individual herbal compounds: $15 \mu \mathrm{M}$ Echinacoside inhibited the activity of MTHI by $>80 \%$; $(\mathrm{C})$ the chemical structure of Echinacoside: a polyphenol glycoside consisting of a phenylpropanoid (red box) and a phenylethanoid (blue box) glycosidically linked to a trisaccharide moiety (a central rhamnose and two side glucose); and (D) a dose-response curve of MTHI inhibition by a natural compound: Echinacoside inhibited MTHI with an $\mathrm{IC}_{50}$ of $7.0 \mathrm{I} \pm 2.13 \mu \mathrm{M}$.

Abbreviations: $\mathrm{IC}_{50}$, inhibitory concentration; dGTP, deoxyguanosine triphosphate. 


\section{Echinacoside inhibited cellular MTHI to increase intracellular 8-oxoG}

Next, we asked if Echinacoside can inhibit intracellular MTH1 activity. Inhibition of cellular MTH1 will result in the increase of intracellular 8-oxoG. Avidin has been shown to bind to 8 -oxoG with high specificity; ${ }^{42}$ therefore, we used immunofluorescent staining with Cy3-conjugated avidin to compare intracellular 8-oxoG levels in various cancer cell lines before and after Echinacoside treatment. Human MG-63 osteosarcoma, SK-HEP-1 hepatocarcinoma,
MCF-7 breast cancer, and SW480 colorectal cancer cells were treated with $0 \mu \mathrm{M}, 15 \mu \mathrm{M}, 30 \mu \mathrm{M}, 60 \mu \mathrm{M}$, or $80 \mu \mathrm{M}$ Echinacoside for 5 hours, 12 hours, or 24 hours. Staining with Cy3-conjugated avidin revealed that treatment with $60 \mu \mathrm{M}$ Echinacoside for 24 hours clearly and significantly increased the level of cellular 8-oxoG ( $\mathrm{Cy} 3$-avidin reactive substance) in these cancer cells (Figure 2A and B). Higher concentration $(80 \mu \mathrm{M})$ of Echinacoside resulted in stronger cellular 8-oxoG staining (Figure 2B), suggesting a dose-response relationship. Similar results were obtained
A
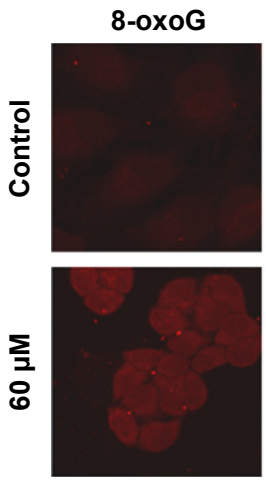

C

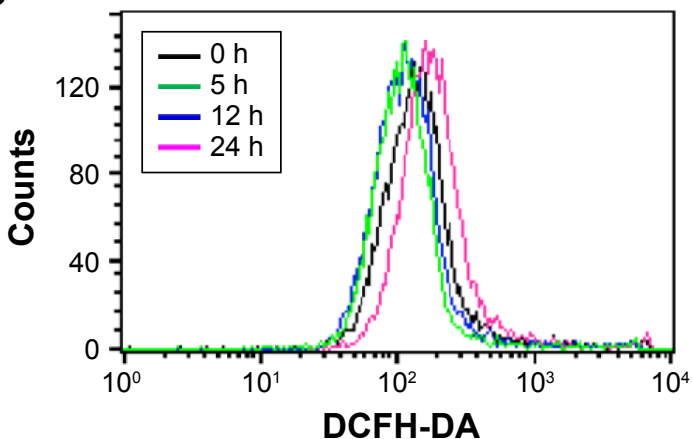

E
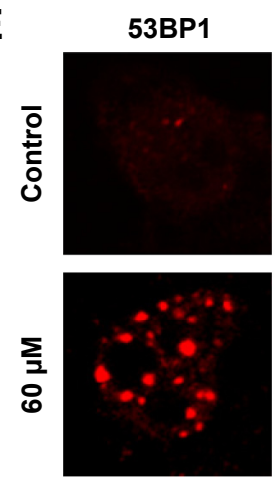

DAPI
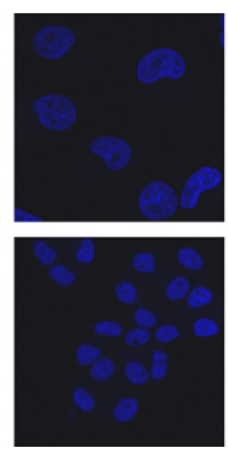

CFH-DA
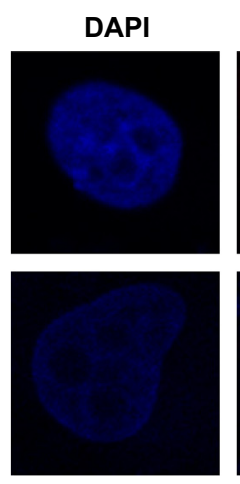

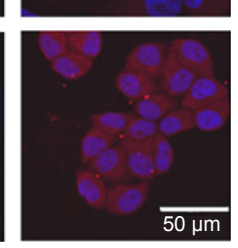

$\overline{50 \mu m}$

Merge
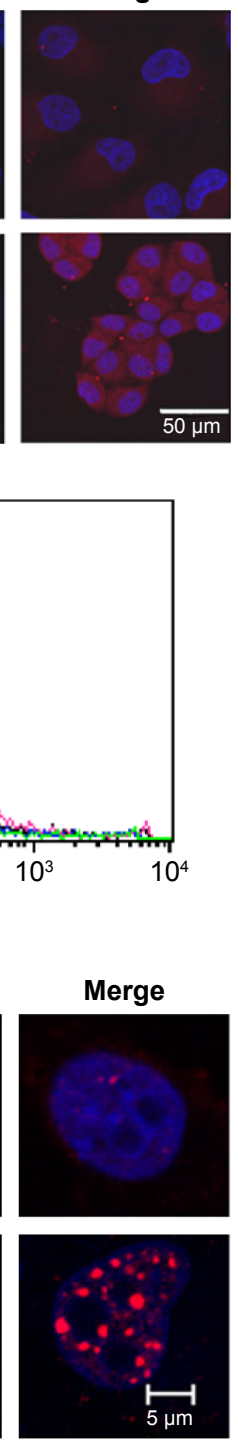

B

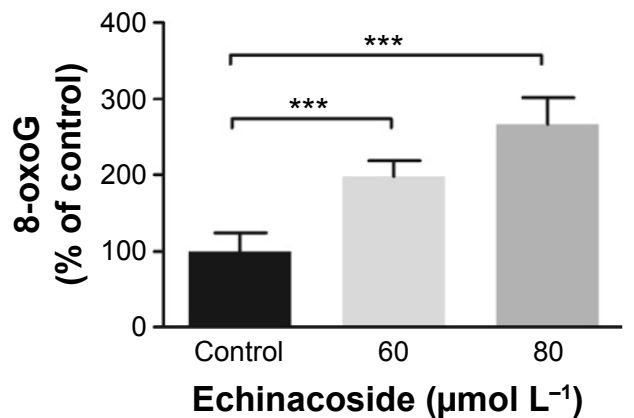

D

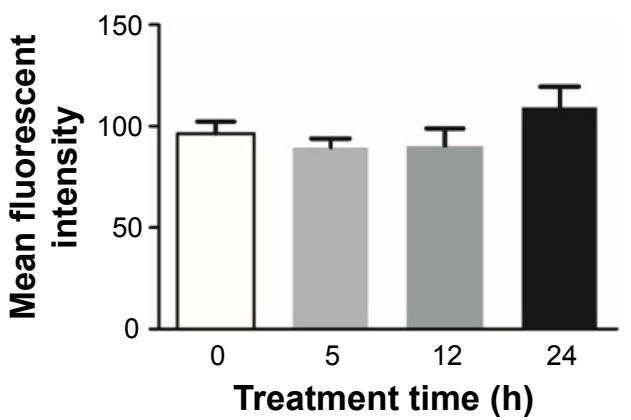

$\mathbf{F}$

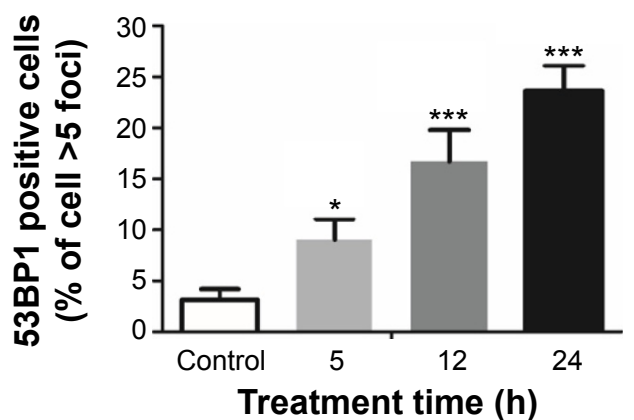

Figure 2 Examination of cellular 8-oxoG, ROS, and DNA damages.

Notes: (A) Detection of 8-oxoG by staining with Cy3-conjugated avidin, (B) quantification of data from three independent experiments: treatment of MG-63 cells with $60 \mu \mathrm{M}$ Echinacoside for $24 \mathrm{~h}$ significantly increased the level of cellular 8-oxoG (Cy3-avidin reactive substance) $(* * * P<0.00 \mathrm{I}$ vs vehicle control), (C) measurement of cellular ROS by flow cytometry, (D) quantification of data from three independent experiments: treatment of MG-63 cells with $60 \mu \mathrm{M}$ Echinacoside for 5 h, 12 h, or 24 h did not change cellular ROS level, (E) immunofluorescent staining of nuclear 53BPI, and (F) quantification of data from three coverslips: significant increase in the number of cells with five or more bright 53BPI foci was seen as early as $5 \mathrm{~h}$ after initiation of treatment with $60 \mu \mathrm{M}$ Echinacoside $(* P<0.05$, $* * * P<0.00 \mathrm{l}$ vs vehicle control).

Abbreviations: 8-oxoG, 8-oxoguanine; ROS, reactive oxygen series; DAPI, 4',6-diamidino-2-phenylindole; DCFH-DA, dichloro-dihydro-fluorescein diacetate; h, hours. 
by immunofluorescent staining with a mouse monoclonal anti-8-oxoG antibody (Figure S1A) ${ }^{43}$ The concentration of Echinacoside $(60 \mu \mathrm{M})$ required for a significant increase in cellular 8-oxoG was much higher than the $\mathrm{IC}_{50}(7.01 \mu \mathrm{M})$ from the in vitro assay. This was likely due to the difference in sensitivity of the two assays. Immunofluorescent staining is far less sensitive than the in vitro enzymatic assay; furthermore, the number of inhibitor molecules that can reach and interact with cellular MTH1 is influenced by complex biological processes; additionally, in the in vitro assay, the less favorite dGTP is used as the substrate, and hence it may be easier (take fewer inhibitors) to inhibit MTH1, resulting in a lower $\mathrm{IC}_{50}$ in the in vitro assay.

Cellular 8-oxoG is generated by ROS, which is antagonized by antioxidants. Thus, increase in cellular ROS or suppression of the activity of antioxidants would also result in increase in cellular 8-oxoG level. Echinacoside itself is a potent antioxidant ${ }^{44,45}$ and thus should enhance rather than suppress the activity of antioxidants. To examine if cellular ROS level was changed by Echinacoside treatment, the same cancer cells were treated with $0 \mu \mathrm{M}, 15 \mu \mathrm{M}, 30 \mu \mathrm{M}, 60 \mu \mathrm{M}$, or $80 \mu \mathrm{M}$ Echinacoside for 5 hours, 12 hours, or 24 hours and then analyzed by flow cytometry after staining with the fluorescent probe $2^{\prime}, 7^{\prime}$-dichlorofluorescin diacetate. The results showed that none of these treatments changed cellular ROS level (Figure 2C and D). Thus, the increased cellular 8-oxoG level was most likely resulted from the inhibition of MTH1 by Echinacoside.

\section{Echinacoside caused extensive DNA damages specifically in cancer cells}

Incorporation of 8-oxoG into DNA will stimulate BER and MMR, which generate single-strand DNA breaks (SSB) and gaps. ${ }^{16,17}$ Normally, these breaks and gaps are sealed by repair mechanisms involving gap filling and ligation by DNA polymerases and ligases. ${ }^{46,47}$ However, rapid increases in cellular SSB can saturate cellular repair capacity, leading to the formation of numerous double-strand DNA breaks (DSB) $)^{18}$ and DDR signaling. To examine if the Echinacoside-induced increase in cellular 8-oxoG caused DNA damages, we examined one of the early markers of DNA damage, 53BP1, which binds to sites of DSB as an earliest cellular response to DSB.48 The MG-63, SK-HEP-1, MCF-7, and SW480 cancer cell lines and the noncancer cell lines human normal liver L-O2, ${ }^{49}$ human embryonic kidney HEK 293, and mouse fibroblast $\mathrm{NIH} / 3 \mathrm{~T} 3$ were treated with $0 \mu \mathrm{M}, 15 \mu \mathrm{M}, 30 \mu \mathrm{M}, 60 \mu \mathrm{M}$, or $80 \mu \mathrm{M}$ Echinacoside for 5 hours, 12 hours, or 24 hours. Fluorescent immunostaining showed that treatment with
$60 \mu \mathrm{M}$ Echinacoside for 24 hours specifically increased the number of cells with five or more strongly stained nuclear 53BP1 foci in all the cancer but not in any of the noncancer cell lines (Figure 2E and F). Significant increase in the number of $53 \mathrm{BP}^{+}$cells was seen as early as 5 hours after initiation of Echinacoside treatment (Figure 2F). Higher concentration $(80 \mu \mathrm{M})$ of Echinacoside or longer treatment time (12 hours and 24 hours) resulted in larger increases in both the number of 53BP $1^{+}$cells (Figure $2 \mathrm{~F}$ ) and the number of cellular 53BP1 foci. Together, these results suggest that the inhibition of MTH1 by Echinacoside caused 8-oxoG accumulation and extensive DNA damages in cancer but not in noncancer cells.

\section{Echinacoside suppressed cancer cell proliferation}

In cycling cells, unrepaired DNA strand breaks will cause collapse of DNA replication forks, which will then lead to blockage of cell proliferation by induction of cell cycle arrest and apoptosis. ${ }^{50}$ To check the effects of Echinacoside on cell growth and proliferation, we first analyzed the growth of Echinacoside-treated MG-63, SK-HEP-1, MCF-7, and SW480 cancer cells by a colony formation assay. The results showed that the cancer cells treated with $60 \mu \mathrm{M}$ or $80 \mu \mathrm{M}$ Echinacoside formed much fewer colonies, and the colonies that formed were much smaller (Figure 3A and B), indicating greatly suppressed growth potential. Next, we analyzed the proliferation of these cancer cells, together with the L-O2, HEK 293, and NIH/3T3 noncancer cells by an MTT assay. The results showed that Echinacoside dose dependently inhibited the proliferation of the cancer but not the noncancer cells (Figure 3C). Time-course study of cancer cells treated with $60 \mu \mathrm{M}$ Echinacoside showed that after 5 hours, there was no significant difference between nontreatment and treatment groups, but after 12 hours, cancer cell proliferation was significantly inhibited by $60 \mu \mathrm{M}$ Echinacoside (Figure 3D).

\section{Echinacoside induced cell cycle arrest}

In accordance with the observations on cell growth and proliferation, Western blot analysis showed that 24 hours treatment with $60 \mu \mathrm{M}$ and $80 \mu \mathrm{M}$ Echinacoside significantly increased the protein level of the $\mathrm{G}_{1} / \mathrm{S}-\mathrm{CDK}$ blocker and DNA synthesis inhibitor $\mathrm{p} 21^{\mathrm{Cip} / \mathrm{WAF} 1}$ in the MG-63, SK-HEP-1, MCF-7, and SW480 cancer cells (Figure 4A and B). Moreover, similar to 53BP1, significant increase in $\mathrm{p} 21$ protein level was seen as early as 5 hours after initiation of Echinacoside treatment (Figure 4B). Analysis of the number of cells at different 


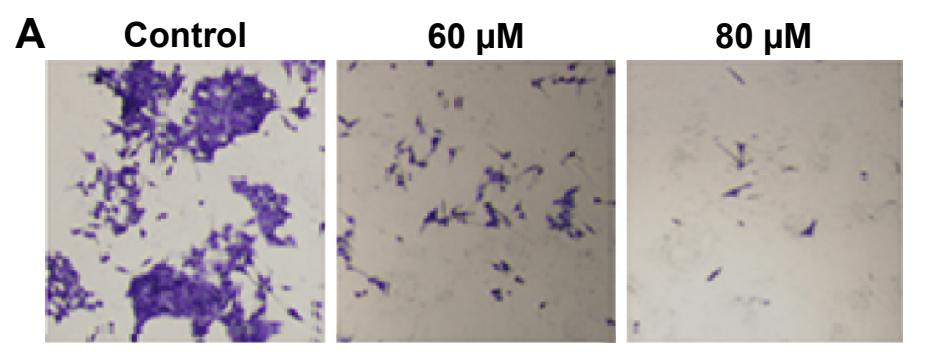

C

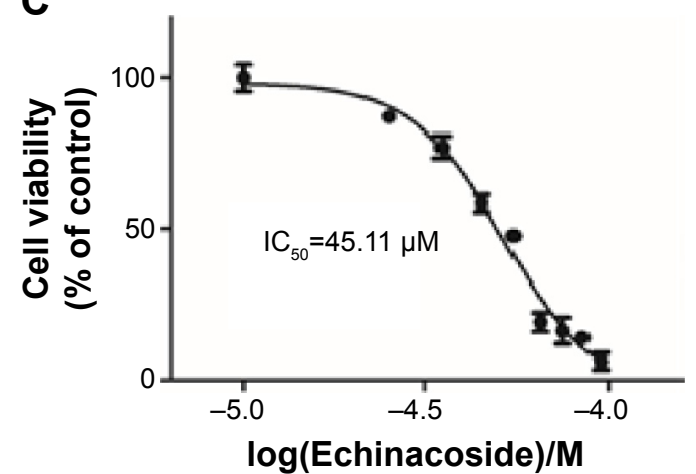

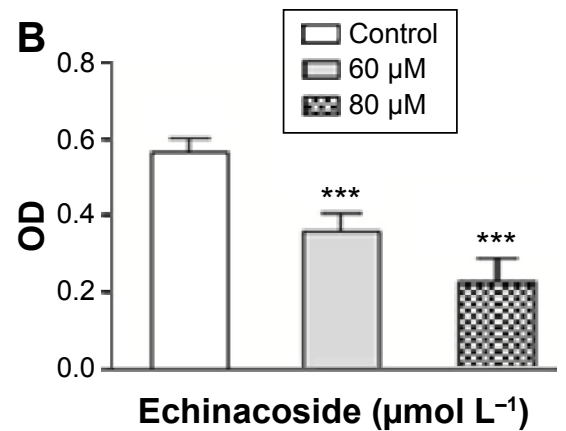

D

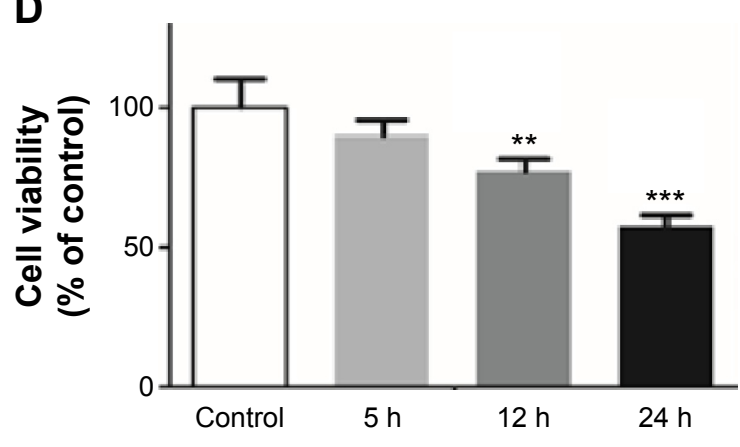

Figure 3 Analysis of cell growth and proliferation.

Notes: (A and B) Colony formation assay: MG-63 cells treated with $60 \mu \mathrm{M}$ or $80 \mu \mathrm{M}$ Echinacoside for 7 days formed significantly fewer and smaller colonies ( $* * * P<0.00$ I

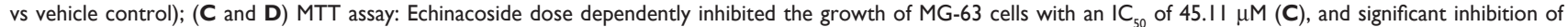
proliferation was seen $12 \mathrm{~h}$ after initiation of treatment with $60 \mu \mathrm{M}$ Echinacoside (D) $(* * P<0.0 \mathrm{I}$, $* * * P<0.00 \mathrm{I}$ vs vehicle control).

Abbreviations: MTT, 3-(4,5-dimethylthiazol-2-yl)-2,5-diphenyltetrazolium bromide; IC ${ }_{50}$, inhibitory concentration; h, hours; OD, optical density.

stages of cell cycle by flow cytometry revealed that Echinacoside treatment dose dependently reduced the percentage of cells in both $S$ and $\mathrm{G}_{2} / \mathrm{M}$ phases, while the percentage of cells in $\mathrm{G}_{1}$ phase increased (Figure $4 \mathrm{C}$ and D). After $80 \mu \mathrm{M}$ Echinacoside treatment of MG-63 cells for 24 hours, cells in $\mathrm{G}_{2} / \mathrm{M}$ phase decreased from $15 \%$ to nearly zero, and cells in $\mathrm{S}$ phase decreased from $37 \%$ to $17 \%$, while cells in $\mathrm{G}_{0 / 1}$ phase increased from $43 \%$ to $80 \%$ (Figure $4 \mathrm{E}$ ). These results indicate that treatment with Echinacoside induced cell cycle arrest and blocked the cancer cells in $\mathrm{G}_{1}$ phase.

\section{Echinacoside induced apoptosis in cancer cells}

Consistent with observations on cell proliferation, Western blot analysis showed that treatment with $60 \mu \mathrm{M}$ and $80 \mu \mathrm{M}$ Echinacoside for 24 hours increased the levels of active caspase- 3 and cleaved poly (ADP-ribose) polymerase proteins in the cancer cells (Figure 5A and B), suggesting induction of caspase-dependent apoptosis. We then examined several cellular markers of apoptosis. First, the nuclear morphology of Echinacoside-treated cancer cells was revealed by staining with the DNA dye DAPI, which showed that 24 hours treatment with $60 \mu \mathrm{M}$ and $80 \mu \mathrm{M}$ Echinacoside increased the number of hallmarks of apoptosis, including pyknosis and condensed chromatin (brighter nuclei) (Figure 5C). Second, the DNA extracted from similarly treated cancer cells was analyzed by electrophoresis on agarose gel, which revealed a typical apoptotic ladder pattern (Figure S1B). Finally, cellular active caspase-3 was detected by immunofluorescent staining, which revealed strong activated caspase-3 signals in Echinacoside-treated cancer cells (Figure S1C).

Next, the percentage of apoptotic cells was measured by Annexin V-FITC and PI double staining and flow cytometry. Analysis of cells treated with $0 \mu \mathrm{M}, 15 \mu \mathrm{M}, 30 \mu \mathrm{M}$, $60 \mu \mathrm{M}, 80 \mu \mathrm{M}$, or $160 \mu \mathrm{M}$ Echinacoside for 2 hours, 5 hours, 12 hours, or 24 hours showed that $60 \mu \mathrm{M}$ or higher concentrations of Echinacoside induced significant apoptosis in the MG-63, SK-HEP-1, MCF-7, and SW480 cancer cells (Figure 6A), but not in the noncancer L-O2, HEK 293, and NIH/3T3 cells (Figure S2). After treatment of MG-63 cells with $60 \mu \mathrm{M}, 80 \mu \mathrm{M}$, or $160 \mu \mathrm{M}$ Echinacoside for 24 hours, the percentage of apoptotic cells increased from $8.89 \%$ to $33.72 \%, 39.01 \%$, and $48.12 \%$, respectively (Figure 6A). Time-course study showed that after 5 hours, there was no significant difference between nontreatment and treatment groups, but significant apoptosis was seen after treatment with $60 \mu \mathrm{M}$ or higher concentrations of Echinacoside for 12 hours (Figures 6B and S3). 

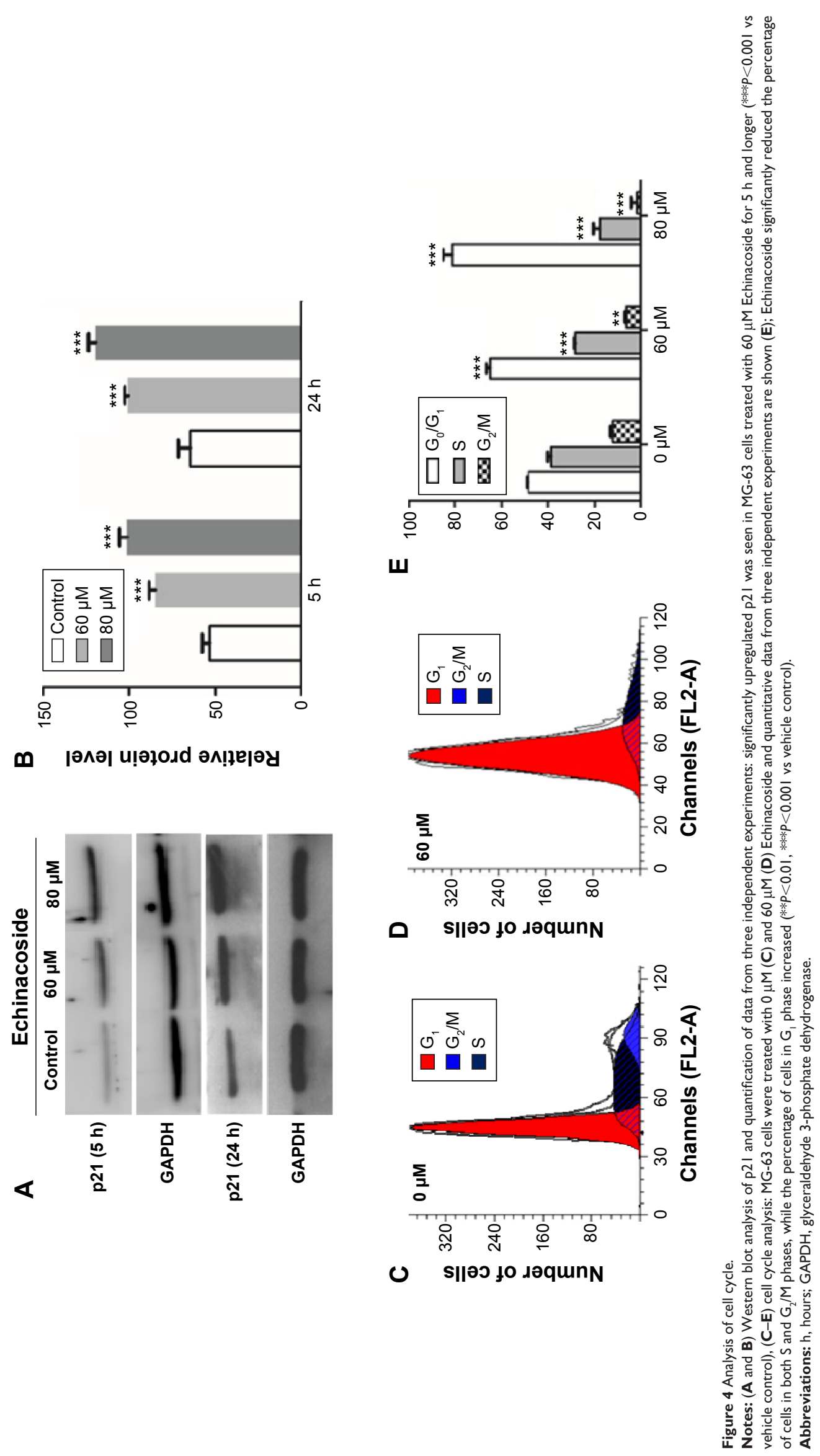
A

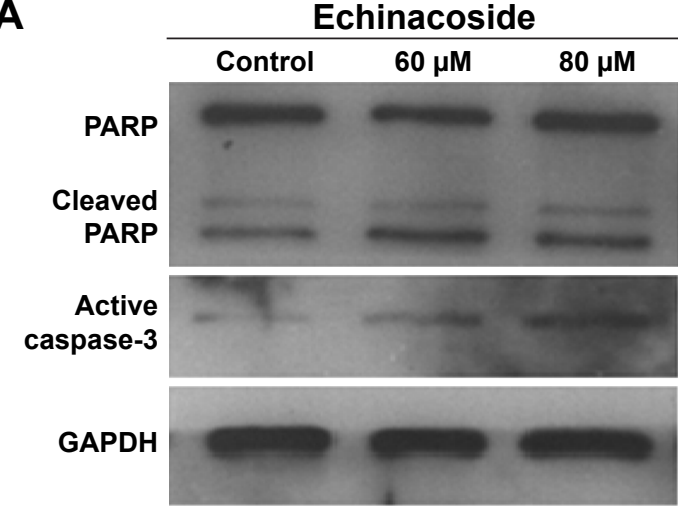

B

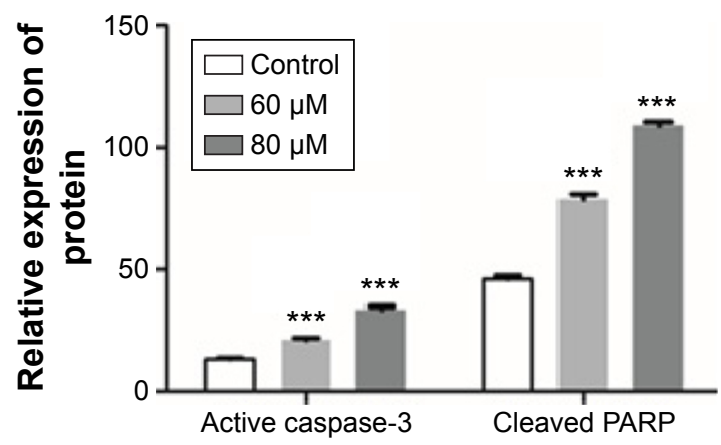

C

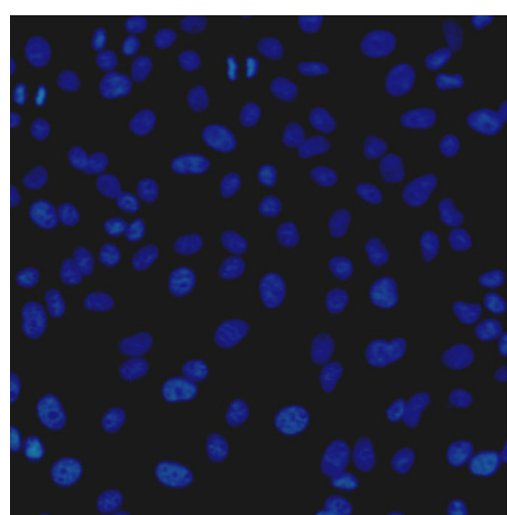

$60 \mu \mathrm{M}$

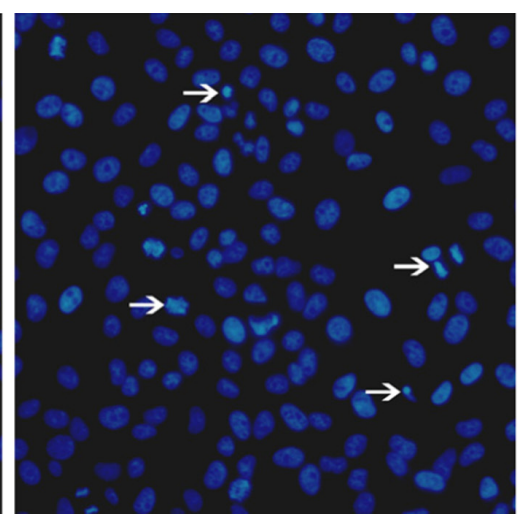

$80 \mu \mathrm{M}$

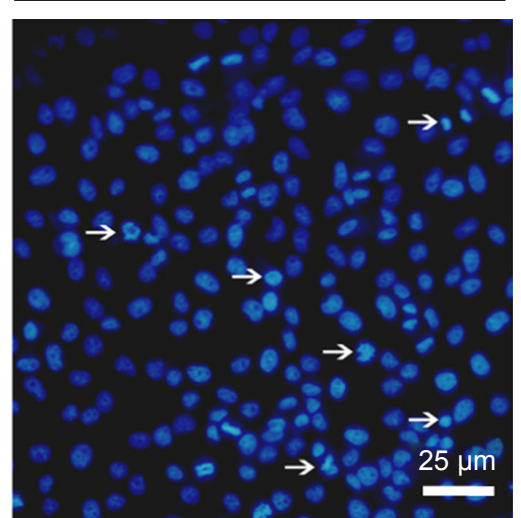

Figure 5 Analysis of apoptosis.

Notes: (A) Western blot detection of cleaved PARP and active caspase-3 proteins, (B) quantification of data from three independent experiments: treatment with $60 \mu \mathrm{M}$ or $80 \mu \mathrm{M}$ Echinacoside for $24 \mathrm{~h}$ increased the levels of cleaved PARP and active caspase-3 proteins in MG-63 cells (***P<0.00I vs vehicle control), and (C) images of DAPIstained nuclei: MG-63 cells were treated with $0 \mu \mathrm{M}, 60 \mu \mathrm{M}$, and $80 \mu \mathrm{M}$ Echinacoside for $24 \mathrm{~h}$, some apoptotic cells were marked by white arrows.

Abbreviations: PARP, poly (ADP-ribose) polymerase; h, hours; DAPI, 4',6-diamidino-2-phenylindole; GAPDH, glyceraldehyde 3-phosphate dehydrogenase.

Finally, measurement of mitochondrial membrane potential by the JC-1 fluorescent dye clearly showed a prominent loss of mitochondrial membrane potential after treatment with $60 \mu \mathrm{M}$ Echinacoside for 12 hours (Figure 6C), but not after 5 hours, indicating the activation of the intrinsic apoptosis pathway following the DNA damages caused by elevated 8-oxodG.

\section{Discussion}

Echinacoside is a natural compound isolated from the medicinal plants Cistanche and Echinacea. ${ }^{51,52}$ It has been shown to possess versatile health promotional and disease preventive properties, including neural protection, hepatoprotection, and anti-inflammation, antifatigue, antisenescence, antidiabetes, and antitumor activities. ${ }^{53-58}$ The best known and accepted bioactivity of Echinacoside is its antioxidative and ROSscavenging action; ${ }^{44,45}$ however, it has also been shown to cause oxidative DNA damages in cancer cells, with the underlying mechanisms remaining unclear. ${ }^{58}$ In the present study, using a high-throughput in vitro screening assay, we found that Echinacoside effectively inhibited the MTH1-catalyzed enzymatic reaction. Increasing the amount of the MTH1 enzyme decreased the degree of inhibition, while increasing the amount of the inorganic pyrophosphatase did not affect the inhibition, indicating that Echinacoside specifically inhibited the activity of MTH1 in the in vitro assay. Treatment of different human cancer cell lines with Echinacoside caused significant elevation of cellular 8-oxoG level without changing the cellular ROS level. Given that Echinacoside itself is a potent antioxidant, these results suggested that the increased intracellular 8-oxoG level was likely resulted from the inhibition of cellular MTH1 by Echinacoside.

Treatment with Echinacoside caused extensive DNA damages and significant upregulation of the $\mathrm{G}_{1} / \mathrm{S}$-CDK blocker p21, which were followed by marked apoptotic cell death and suppression of cell proliferation specifically in cancer but not in the noncancer cells. Furthermore, a prominent loss of mitochondrial membrane potential after 


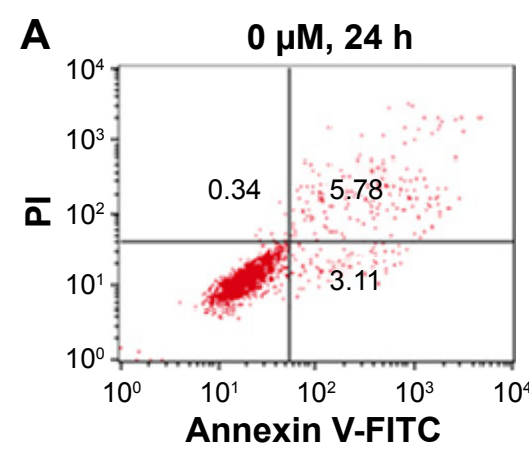

C

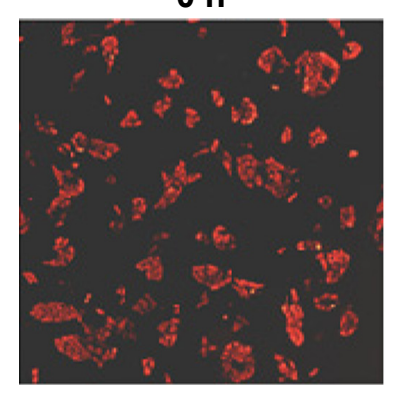

$60 \mu \mathrm{M}, 24 \mathrm{~h}$

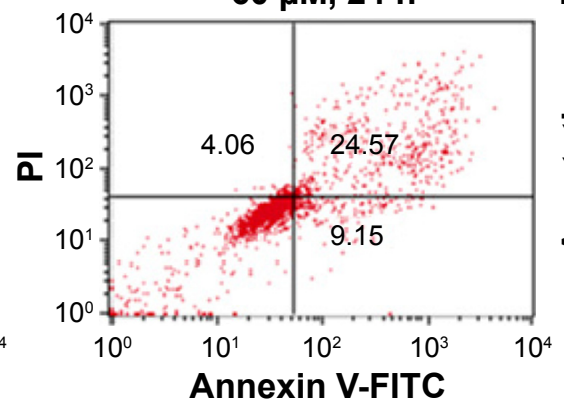

B

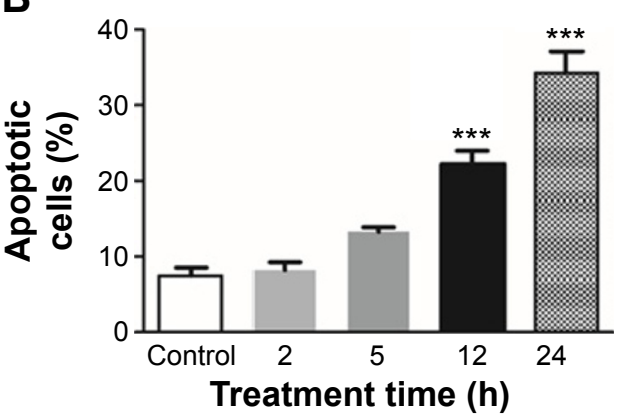

Figure 6 Induction of apoptosis by Echinacoside.

Notes: (A) Analysis of Annexin V-FITC- and propidium iodide-stained cells by flow cytometry, (B) time-course analysis of apoptosis induction: significant apoptosis was seen in MG-63 cells treated with $60 \mu \mathrm{M}$ or higher concentrations of Echinacoside for $12 \mathrm{~h}(* * * \mathrm{p}<0.00 \mathrm{I}$ vs control), and (C) measurement of mitochondrial membrane potential: MG-63 cells were treated with $60 \mu \mathrm{M}$ Echinacoside for $5 \mathrm{~h}, 12 \mathrm{~h}$, and $24 \mathrm{~h}$; increase in the intensity of green at the $12 \mathrm{~h}$ point showed significant disruption of mitochondrial membrane potential.

Abbreviations: h, hours; PI, propidium iodide; FITC, fluorescein isothiocyanate.

Echinacoside treatment indicated activation of the intrinsic apoptosis pathway. Echinacoside-induced DNA damages and upregulation of p21 were observed within 5 hours of treatment, while cancer cell apoptosis, disruption of mitochondrial membrane potential, and growth inhibition were observed 12 hours after initiation of treatment. These data support that cancer cell apoptosis and growth inhibition were the results of the extensive DNA damages caused by the inhibition of MTH1. Recent studies have shown that reduction in the size of cellular dNTP pool could also induce DNA replication stress and DNA damages. ${ }^{59,60}$ However, $>200 \%$ increase in 8-oxoG level in the Echinacoside-treated cancer cells argues against the possibility of a reduced dNTP pool size, and $\mathrm{Bcl} 2$, a protein that reduces dNTP pool size, ${ }^{60}$ was significantly decreased in Echinacoside-treated SW480 cancer cells $;{ }^{58}$ moreover, our data clearly showed that Echinacoside directly inhibited MTH1, which could at least be partially responsible for the DNA damages and cellular effects caused by Echinacoside.

The dNTP pool is a critical target of ROS, and oxidized dNTPs are important sources of oxidative DNA damages., ${ }^{3,10}$ Repair-associated DNA SSBs and DSBs can lead to cellular senescence and apoptosis, which are implicated in aging and aging-related diseases, ${ }^{61}$ and also serve as a barrier for tumorigenesis. Thus, reducing ROS-induced DNA damages by antioxidants are believed to be beneficial to the overall health. However, several recent studies have shown that antioxidants could also promote development of some types of cancer. ${ }^{62-64}$ Cancer cells generate much higher ROS and are critically dependent on efficient elimination of oxidized nucleotides for survival and proliferation. ${ }^{3,30,32,33}$ Overexpression of MTH1 is the most important strategy cancer cells use to cope with the lethal burden of oxidized dNTPs. ${ }^{23,24,26-28}$ Inhibition of MTH1 efficiently killed cancer cells, ${ }^{3,29,30,32,33}$ while targeting MTH1 in normal cells had no impact on survival, ${ }^{32,33}$ and MTH1 knockout mice were largely normal. ${ }^{65}$ Consistently, we also showed that treatment with Echinacoside induced apoptosis and suppressed cell proliferation specifically in cancer but not in noncancer cells. Thus, unlike current chemotherapies and radiotherapies that target normal and tumor cells indiscriminately, the inhibition of MTH1 kills cancer cells highly selectively by using the abundant oxidized nucleotide precursors in tumors. On the other hand, therapies targeting genotype differences between normal and specific types of cancer in a personalized approach have shown impressive results, but they are also limited by the 
high degree of intratumor heterogeneity and high mutation rates in cancer cells. In contrast, inhibition of MTH1 targets a phenotype that distinguishes most cancer cells from normal cells, and hence represents a novel anticancer strategy that is not limited by genetic adaptations. Interestingly, small molecule antagonists of the antiapoptosis protein $\mathrm{Bcl} 2^{66,67}$ and agonists of the proapoptosis $\mathrm{Bax}^{68}$ have been developed and were demonstrated to be promising novel anticancer agents. Given their complementary mechanisms of action, combining MTH1 inhibitors and apoptosis-promoting chemicals would create an exciting new generation of anticancer drugs.

For the first time, we demonstrated a new function for Echinacoside as an anticancer natural compound. In the in vitro assay, Echinacoside inhibited MTH1 with an $\mathrm{IC}_{50}$ of $7.01 \mu \mathrm{M}$. This $\mathrm{IC}_{50}$ value is higher than that of the MTH1 inhibitors reported so far. ${ }^{32,33,69}$ Using $(S)$-crizotinib as a positive control, we showed that our assay is sevenfold less sensitive than that used by Huber et al. ${ }^{33}$ Thus, the actual $\mathrm{IC}_{50}$ of Echinacoside is likely to be lower. Nevertheless, to develop it as a therapeutic agent, the efficacy of the natural Echinacoside molecule will probably need to be improved. As a natural product that has been used as a herbal medicine for long time, Echinacoside could serve as a good chemical scaffold for developing efficient and probably safe MTH1 inhibitors. ${ }^{37,70}$ Given that natural products have been a rich source of novel chemical scaffolds for rational structurebased drug design, ${ }^{70}$ approaches similar to what we used here, together with the vast interests in natural products for drug discovery, will be useful in finding target-based, effective, and safe new drugs.

\section{Acknowledgment}

This study was supported by a startup fund from Jilin University.

\section{Disclosure}

The authors report no conflicts of interest in this work.

\section{References}

1. Topal MD, Baker MS. DNA precursor pool: a significant target for N-methyl-N-nitrosourea in C3H/10T1/2 clone 8 cells. Proc Natl Acad Sci U S A. 1982;79(7):2211-2215.

2. Ichikawa J, Tsuchimoto D, Oka S, et al. Oxidation of mitochondrial deoxynucleotide pools by exposure to sodium nitroprusside induces cell death. DNA Repair (Amst). 2008;7(3):418-430.

3. Rai P, Onder TT, Young JJ, et al. Continuous elimination of oxidized nucleotides is necessary to prevent rapid onset of cellular senescence. Proc Natl Acad Sci U S A. 2009;106(1):169-174.

4. Katafuchi A, Nohmi T. DNA polymerases involved in the incorporation of oxidized nucleotides into DNA: their efficiency and template base preference. Mutat Res. 2010;703(1):24-31.
5. Freudenthal BD, Beard WA, Perera L, et al. Uncovering the polymerase-induced cytotoxicity of an oxidized nucleotide. Nature. 2015;517(7536):635-639.

6. Dizdaroglu M. Oxidatively induced DNA damage and its repair in cancer. Mutat Res Rev Mutat Res. 2015;763:212-245.

7. Nakabeppu Y. Cellular levels of 8-oxoguanine in either DNA or the nucleotide pool play pivotal roles in carcinogenesis and survival of cancer cells. Int J Mol Sci. 2014;15(7):12543-12557.

8. van Loon B, Markkanen E, Hubscher U. Oxygen as a friend and enemy: how to combat the mutational potential of 8-oxo-guanine. DNA Repair (Amst). 2010;9(6):604-616.

9. Pfeifer GP, Besaratinia A. Mutational spectra of human cancer. Hum Genet. 2009;125(5-6):493-506.

10. Russo MT, Blasi MF, Chiera F, et al. The oxidized deoxynucleoside triphosphate pool is a significant contributor to genetic instability in mismatch repair-deficient cells. Mol Cell Biol. 2004;24(1): 465-474.

11. Kamiya H. Mutagenicity of oxidized DNA precursors in living cells: roles of nucleotide pool sanitization and DNA repair enzymes, and translesion synthesis DNA polymerases. Mutat Res. 2010;703(1): $32-36$.

12. Nagy GN, Leveles I, Vértessy BG. Preventive DNA repair by sanitizing the cellular (deoxy)nucleoside triphosphate pool. FEBS $J$. 2014;281(18):4207-4223

13. McLennan AG. The Nudix hydrolase superfamily. Cell Mol Life Sci. 2006;63(2):123-143.

14. Fujikawa K, Kamiya H, Yakushiji H, Nakabeppu Y, Kasai H. Human MTH1 protein hydrolyzes the oxidized ribonucleotide, 2-hydroxy-ATP. Nucleic Acids Res. 2001;29(2):449-454.

15. Nakabeppu Y, Oka S, Sheng Z, Tsuchimoto D, Sakumi K. Programmed cell death triggered by nucleotide pool damage and its prevention by MutT homolog-1 (MTH1) with oxidized purine nucleoside triphosphatase. Mutat Res. 2010;703(1):51-58.

16. Dizdaroglu M. Oxidatively induced DNA damage: mechanisms, repair and disease. Cancer Lett. 2012;327(1-2):26-47.

17. Bridge G, Rashid S, Martin SA. DNA mismatch repair and oxidative DNA damage: implications for cancer biology and treatment. Cancers (Basel). 2014;6(3):1597-1614.

18. Caldecott KW. Single-strand break repair and genetic disease. Nat Rev Genet. 2008;9(8):619-631.

19. Klement K, Goodarzi AA. DNA double strand break responses and chromatin alterations within the aging cell. Exp Cell Res. 2014;329(1): $42-52$.

20. Schulze A, Harris AL. How cancer metabolism is tuned for proliferation and vulnerable to disruption. Nature. 2012;491(7424):364-373.

21. Cairns RA, Harris IS, Mak TW. Regulation of cancer cell metabolism. Nat Rev Cancer. 2011;11(2):85-95.

22. Rai P. Human Mut T homolog 1 (MTH1): a roadblock for the tumorsuppressive effects of oncogenic RAS-induced ROS. Small GTPases. 2012;3(2):120-125.

23. Kennedy CH, Cueto R, Belinsky SA, Lechner JF, Pryor WA. Overexpression of hMTH1 mRNA: a molecular marker of oxidative stress in lung cancer cells. FEBS Lett. 1998;429:17-20.

24. Lida T, Furuta A, Kawashima M, Nishida J, Nakabeppu Y, Iwaki T. Accumulation of 8-oxo-2'-deoxyguanosine and increased expression of hMTH1 protein in brain tumors. Neuro Oncol. 2001;3:73-81.

25. Coskun E, Jaruga P, Jemth AS, et al. Addiction to MTH1 protein results in intense expression in human breast cancer tissue as measured by liquid chromatography-isotope-dilution tandem mass spectrometry. DNA Repair (Amst). 2015;33:101-110.

26. Tudek B, Winczura A, Janik J, Siomek A, Foksinski M, Olinski R. Involvement of oxidatively damaged DNA and repair in cancer development and aging. Am J Transl Res. 2010;2(3):254-284.

27. Speina E, Arczewska KD, Gackowski D, et al. Contribution of hMTH1 to the maintenance of 8-oxoguanine levels in lung DNA of non-smallcell lung cancer patients. J Natl Cancer Inst. 2005;97(5):384-395. 
28. Kennedy CH, Pass HI, Mitchell JB. Expression of human MutT homologue (hMTH1) protein in primary non-small-cell lung carcinomas and histologically normal surrounding tissue. Free Radic Biol Med. 2003;34(11):1447-1457.

29. Rai P, Young JJ, Burton DG, Giribaldi MG, Onder TT, Weinberg RA. Enhanced elimination of oxidized guanine nucleotides inhibits oncogenic RAS-induced DNA damage and premature senescence. Oncogene. 2011;30(12):1489-1496.

30. Sakumi K, Tominaga Y, Furuichi M, et al. Ogg1 knockout-associated lung tumorigenesis and its suppression by Mth1 gene disruption. Cancer Res. 2003;63:902-905.

31. Patel A, Burton DG, Halvorsen K, et al. MutT homolog 1 (MTH1) maintains multiple KRAS-driven pro-malignant pathways. Oncogene. 2015;34(20):2586-2596.

32. Gad H, Koolmeister T, Jemth AS, et al. MTH1 inhibition eradicates cancer by preventing sanitation of the dNTP pool. Nature. 2014; 508(7495):215-221.

33. Huber KV, Salah E, Radic B, et al. Stereospecific targeting of MTH1 by (S)-crizotinib as an anticancer strategy. Nature. 2014;508(7495) 222-227.

34. Giribaldi MG, Munoz A, Halvorsen K, Patel A, Rai P. MTH1 expression is required for effective transformation by oncogenic HRAS Oncotarget. 2015;6(13):11519-11529.

35. Bauer A, Bronstrup M. Industrial natural product chemistry for drug discovery and development. Nat Prod Rep. 2014;31(1):35-60.

36. Orlikova B, Legrand N, Panning J, Dicato M, Diederich M. Antiinflammatory and anticancer drugs from nature. Cancer Treat Res. 2014; 159:123-143.

37. Li JW, Vederas JC. Drug discovery and natural products: end of an era or an endless frontier? Science. 2009;325(5937):161-165.

38. Liu EH, Qi LW, Wu Q, Peng YB, Li P. Anticancer agents derived from natural products. Mini Rev Med Chem. 2009;9(13):1547-1555.

39. Nobili S, Lippi D, Witort E, et al. Natural compounds for cancer treatment and prevention. Pharmacol Res. 2009;59(6):365-378.

40. Hsiao WL, Liu L. The role of traditional Chinese herbal medicines in cancer therapy - from TCM theory to mechanistic insights. Planta Med. 2010;76(11):1118-1131.

41. Baykov AA, Evtushenko OA, Avaeva SM. A malachite green procedure for orthophosphate determination and its use in alkaline phosphatasebased enzyme immunoassay. Anal Biochem. 1988;171(2):266-270.

42. Struthers L, Patel R, Clark J, Thomas S. Direct detection of 8-oxodeoxyguanosine and 8-oxoguanine by avidin and its analogues. Anal Biochem. 1998;255(1):20-31.

43. Sheng Z, Oka S, Tsuchimoto D, et al. 8-Oxoguanine causes neurodegeneration during MUTYH-mediated DNA base excision repair. J Clin Invest. 2012;122(12):4344-4361.

44. Xiong Q, Kadota S, Tani T, Namba T. Antioxidative effects of phenylethanoids from Cistanche deserticola. Biol Pharm Bull. 1996;19(12): 1580-1585.

45. Hu C, Kitts DD. Studies on the antioxidant activity of Echinacea root extract. J Agric Food Chem. 2000;48(5):1466-1472.

46. Wallace SS, Murphy DL, Sweasy JB. Base excision repair and cancer. Cancer Lett. 2012;327(1-2):73-89.

47. Caldecott KW. DNA single-strand break repair. Exp Cell Res. 2014; 329(1):2-8.

48. Schultz LB, Chehab NH, Malikzay A, Halazonetis TD. p53 binding protein $1(53 \mathrm{BP} 1)$ is an early participant in the cellular response to DNA double-strand breaks. J Cell Biol. 2000;151(7):1381-1390.

49. Li YY, Wang L, Lu CD. An E2F site in the 5'-promoter region contributes to serum-dependent up-regulation of the human proliferating cell nuclear antigen gene. FEBS Lett. 2003;544(1-3):112-118.

50. González Besteiro MA, Gottifredi V. The fork and the kinase: a DNA replication tale from a CHK1 perspective. Mutat Res Rev Mutat Res. 2015;763:168-180.
51. Wang Y, Hao H, Wang G, et al. An approach to identifying sequential metabolites of a typical phenylethanoid glycoside, echinacoside, based on liquid chromatography-ion trap-time of flight mass spectrometry analysis. Talanta. 2009;80(2):572-580.

52. Hudson JB. Applications of the phytomedicine Echinacea purpurea (purple coneflower) in infectious diseases. J Biomed Biotechnol. 2012; 2012:769896.

53. Mulani SK, Guh JH, Mong KK. A general synthetic strategy and the anti-proliferation properties on prostate cancer cell lines for natural phenylethanoid glycosides. Org Biomol Chem. 2014;12(18):2926-2937.

54. Kuo YY, Jim WT, Su LC, et al. Caffeic acid phenethyl ester is a potential therapeutic agent for oral cancer. Int J Mol Sci. 2015;16(5): 10748-10766.

55. Li X, Gou C, Yang H, Qiu J, Gu T, Wen T. Echinacoside ameliorates D-galactosamine plus lipopolysaccharide-induced acute liver injury in mice via inhibition of apoptosis and inflammation. Scand J Gastroenterol. 2014;49(8):993-1000.

56. Gai XY, Tang F, Ma J, et al. Antiproliferative effect of echinacoside on rat pulmonary artery smooth muscle cells under hypoxia. J Pharmacol Sci. 2014;126(2):155-163.

57. Zhu M, Lu C, Li W. Transient exposure to echinacoside is sufficient to activate Trk signaling and protect neuronal cells from rotenone. J Neurochem. 2013;124(4):571-580.

58. Dong L, Yu D, Wu N, et al. Echinacoside induces apoptosis in human SW480 colorectal cancer cells by induction of oxidative DNA damages. Int J Mol Sci. 2015;16(7):14655-14668.

59. Bester AC, Roniger M, Oren YS, et al. Nucleotide deficiency promotes genomic instability in early stages of cancer development. Cell. 2011;145(3):435-446

60. Xie M, Yen Y, Owonikoko TK, et al. Bcl2 induces DNA replication stress by inhibiting ribonucleotide reductase. Cancer Res. 2014;74(1): $212-223$.

61. Ventura I, Russo MT, De Luca G, Bignami M. Oxidized purine nucleotides, genome instability and neurodegeneration. Mutat Res. 2010; 703(1):59-65.

62. DeNicola GM, Karreth FA, Humpton TJ, et al. Oncogene-induced Nrf2 transcription promotes ROS detoxification and tumorigenesis. Nature. 2011;475(7354):106-109.

63. Santos MA, Faryabi RB, Ergen AV, et al. DNA-damage-induced differentiation of leukaemic cells as an anti-cancer barrier. Nature. 2014;514(7520):107-111.

64. Sayin VI, Ibrahim MX, Larsson E, Nilsson JA, Lindahl P, Bergo MO. Antioxidants accelerate lung cancer progression in mice. Sci Transl Med. 2014;6(221):221ra215.

65. Egashira A, Yamauchi K, Yoshiyama K, et al. Mutational specificity of mice defective in the MTH1 and/or the MSH2 genes. DNA Repair (Amst). 2002;1(11):881-893.

66. Vaillant F, Merino D, Lee L, et al. Targeting BCL-2 with the BH3 mimetic ABT-199 in estrogen receptor-positive breast cancer. Cancer Cell. 2013;24(1):120-129.

67. Han B, Park D, Li R, et al. Small-molecule Bcl2 BH4 antagonist for lung cancer therapy. Cancer Cell. 2015;27(6):852-863.

68. Xin M, Li R, Xie M, et al. Small-molecule Bax agonists for cancer therapy. Nat Commun. 2014;5:4935.

69. Streib M, Kraling K, Richter K, Xie X, Steuber H, Meggers E. An organometallic inhibitor for the human repair enzyme 7,8dihydro-8-oxoguanosine triphosphatase. Angew Chem Int Ed Engl. 2014;53(1):305-309.

70. Szychowski J, Truchon JF, Bennani YL. Natural products in medicine: transformational outcome of synthetic chemistry. J Med Chem. 2014;57(22):9292-9308. 


\section{Supplementary materials}

Table SI List of herbal compounds used in the in vitro screening

\begin{tabular}{|c|c|c|c|}
\hline Name & CAS registry number & Catalog \# & Purity \\
\hline Echinacoside & $82854-37-3$ & YY90282 & HPLC $>98 \%$ \\
\hline Quercetin & $117-39-5$ & YY90083 & HPLC $>98 \%$ \\
\hline Scutellarin & $27740-01-8$ & YY900I7 & HPLC $>98 \%$ \\
\hline Magnolol & $528-43-8$ & YY90180 & HPLC $>98 \%$ \\
\hline Jatrorrhizine & $960383-96-4$ & YY90285 & HPLC $>98 \%$ \\
\hline Salidroside & $10338-51-9$ & YY90076 & HPLC $>98 \%$ \\
\hline Hyperoside & $482-36-0$ & YY90090 & HPLC $>98 \%$ \\
\hline Safflomin A & $7828 \mid-02-4$ & YY90380 & HPLC $>98 \%$ \\
\hline Glycyrrhetinic & $1449-05-4$ & YY90038 & HPLC $>98 \%$ \\
\hline Kaempferol & $520-18-3$ & YY90I29 & HPLC $>98 \%$ \\
\hline Rutin & $153-18-4$ & YY90103 & HPLC $>98 \%$ \\
\hline Piperine & $94-62-2$ & YY90200 & HPLC $>98 \%$ \\
\hline
\end{tabular}

Abbreviations: HPLC, high-performance liquid chromatography; CAS, Chemical Abstracts Service.
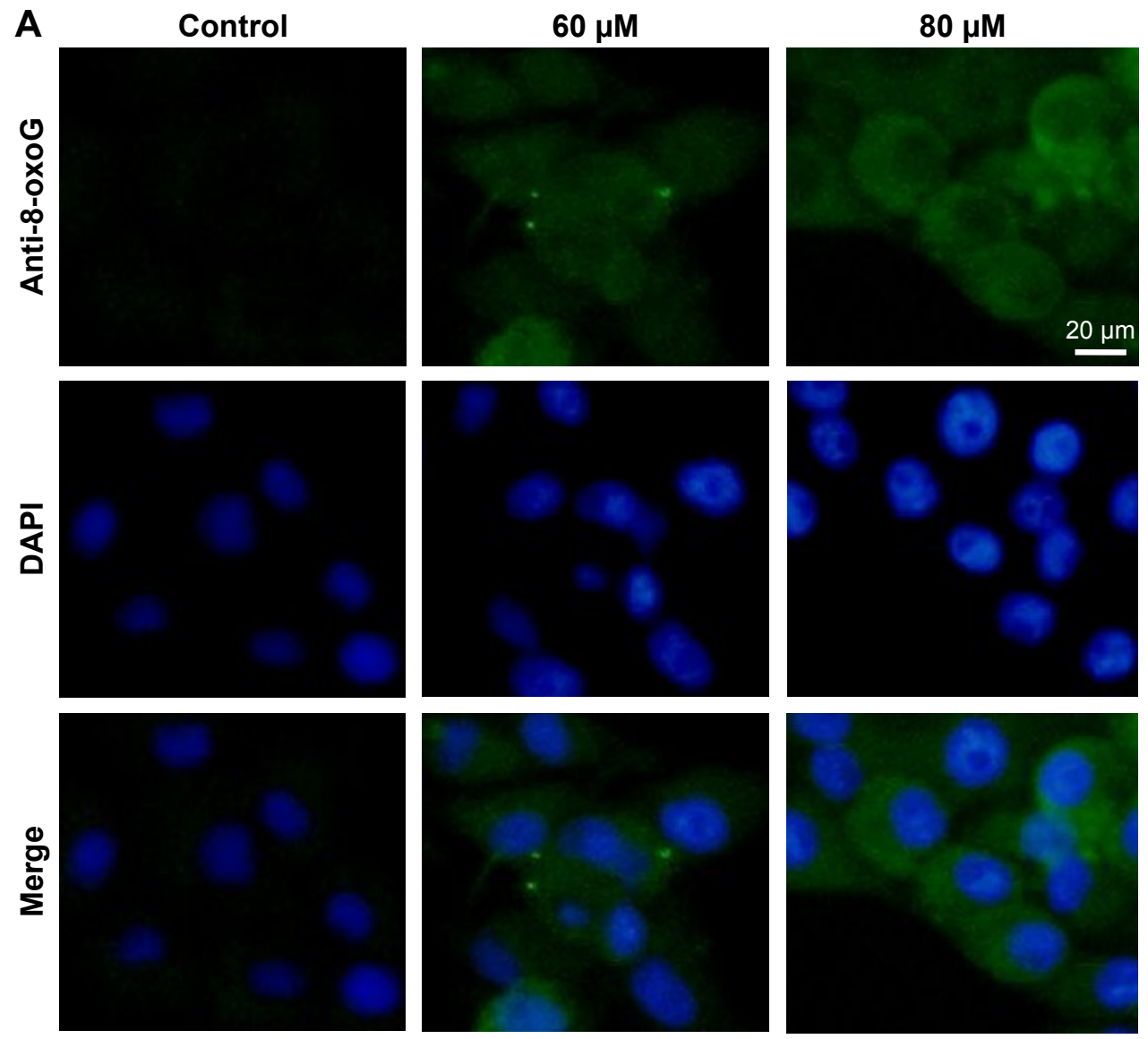

Figure SI (Continued) 


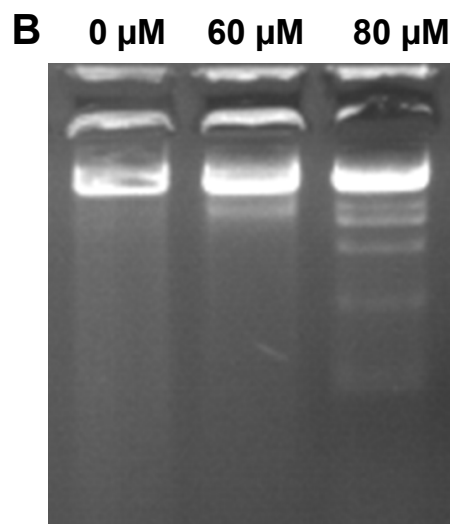

C

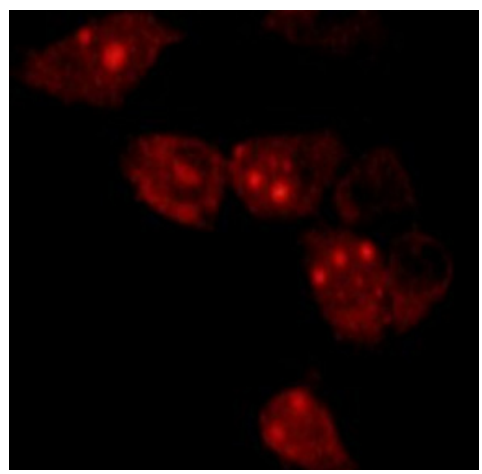

Anti-caspase-3 + DAPI

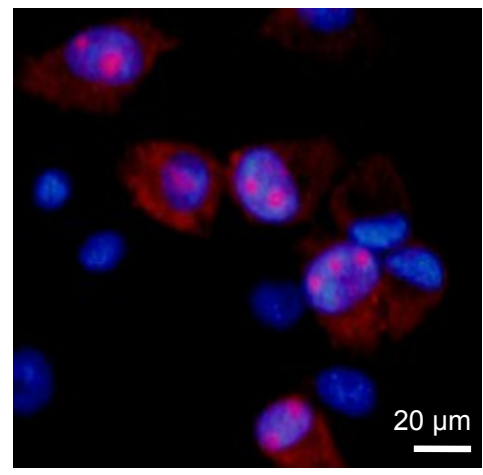

Figure SI Examination of cellular 8-oxoG and apoptosis.

Notes: (A) Detection of 8-oxoG by a monoclonal anti-8-oxoG antibody: 8-oxoG signal was revealed by an Alexa 488-conjugated secondary antibody, and treatment of MG-63 cells with $60 \mu \mathrm{M}$ and $80 \mu \mathrm{M}$ Echinacoside for $24 \mathrm{~h}$ increased the level of 8-oxoG; (B) analysis of cancer cell DNA by electrophoresis on $2 \%$ agarose gel: treatment of MG-63 cells with $80 \mu \mathrm{M}$ Echinacoside for $24 \mathrm{~h}$ produced a typical apoptosis ladder pattern; and (C) immunofluorescent staining of active caspase-3: strongly activated caspase-3 signals were detected in MG-63 cells treated with $60 \mu \mathrm{M}$ Echinacoside for $24 \mathrm{~h}$ Abbreviations: 8-oxoG, 8-oxoguanine; h, hours; DAPI, 4',6-diamidino-2-phenylindole.
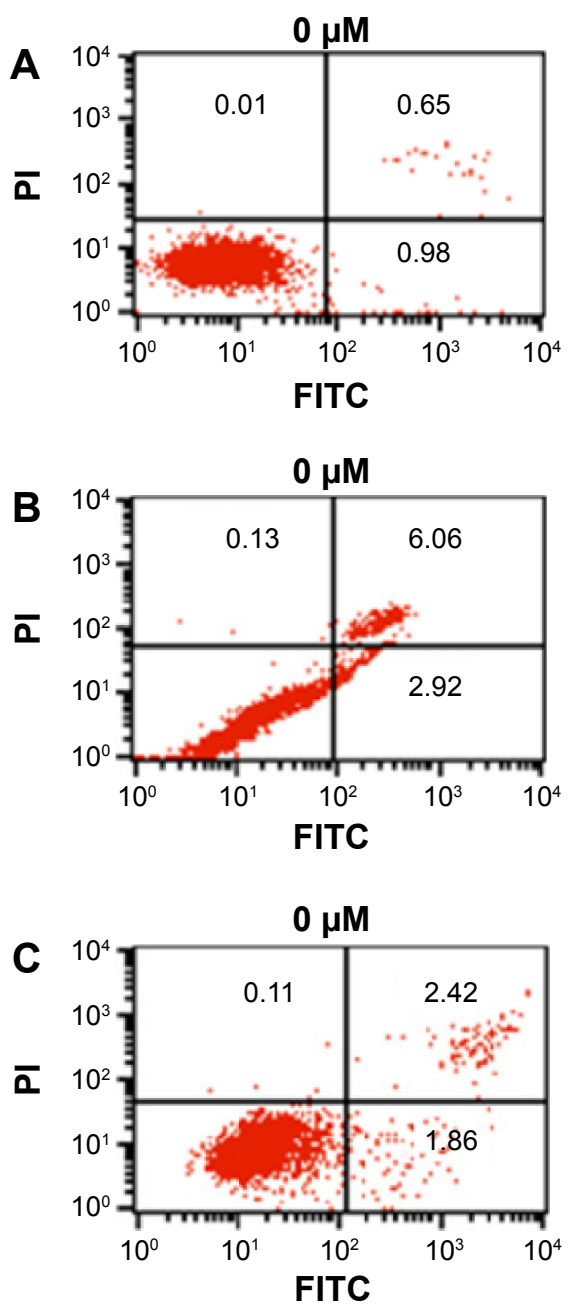
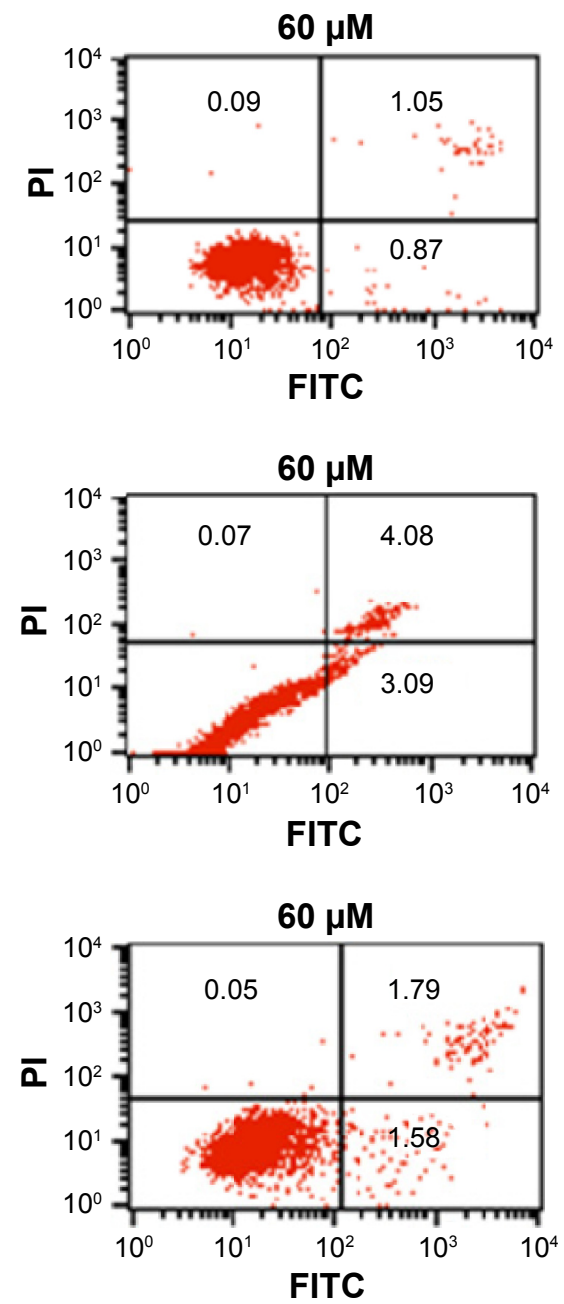
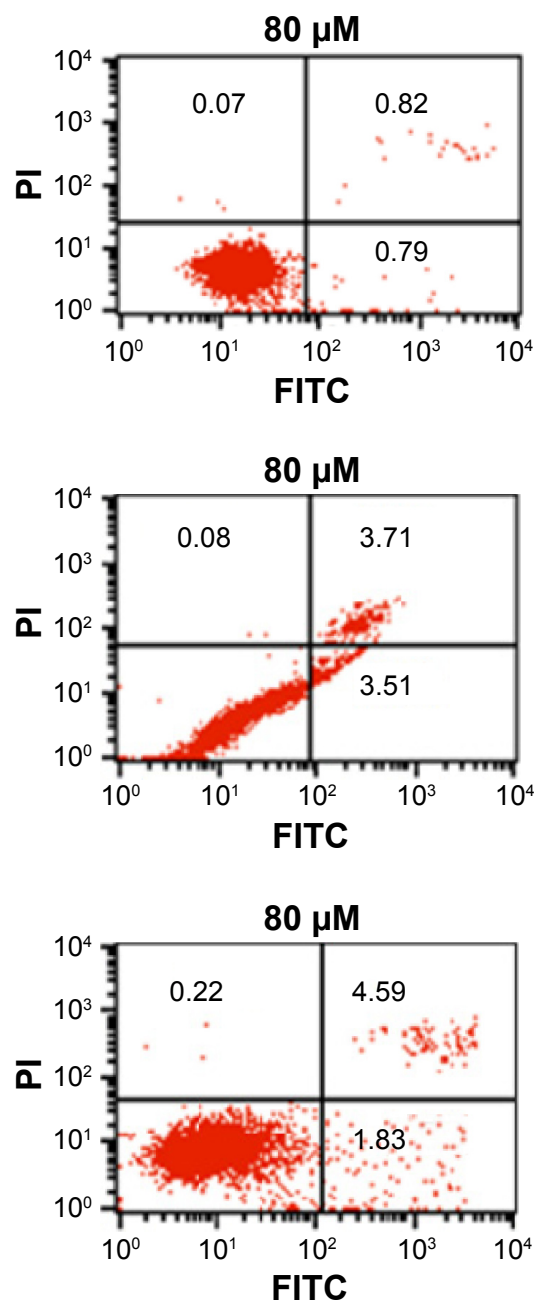

Figure S2 Flow cytometry analysis of apoptosis in noncancer cells.

Notes: (A) Normal human liver L-O2 cells, (B) human embryonic kidney HEK 293 cells, and (C) mouse NIH/3T3 fibroblast cells. Treatment with $60 \mu \mathrm{M}$ and $80 \mu \mathrm{M}$ Echinacoside for $24 \mathrm{~h}$ did not change the percentage of apoptotic cells in these noncancer cell lines.

Abbreviations: h, hours; PI, propidium iodide; FITC, fluorescein isothiocyanate. 

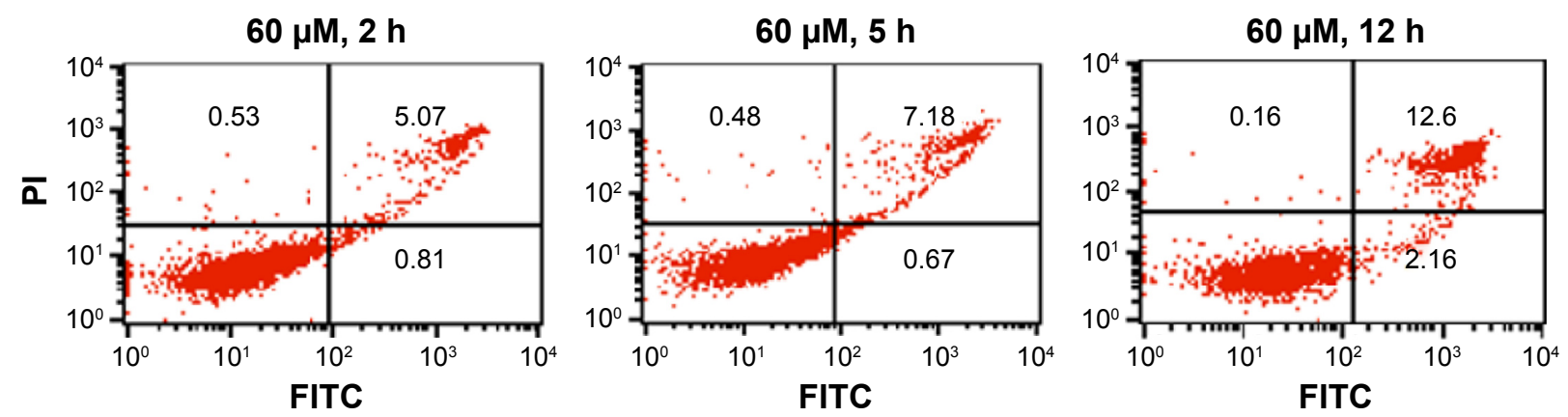

Figure S3 Time-course analysis of apoptosis.

Notes: MG-63 cells were treated with $60 \mu \mathrm{M}$ Echinacoside for $2 \mathrm{~h}, 5 \mathrm{~h}$, and I $2 \mathrm{~h}$, and significant apoptosis was seen after treatment for $12 \mathrm{~h}$.

Abbreviations: $h$, hours; $\mathrm{Pl}$, propidium iodide.

\section{Publish your work in this journal}

OncoTargets and Therapy is an international, peer-reviewed, open access journal focusing on the pathological basis of all cancers, potential targets for therapy and treatment protocols employed to improve the management of cancer patients. The journal also focuses on the impact of management programs and new therapeutic agents and protocols on patient perspectives such as quality of life, adherence and satisfaction. The manuscript management system is completely online and includes a very quick and fair peer-review system, which is all easy to use. Visit http://www.dovepress.com/testimonials.php to read real quotes from published authors. 